\section{Profilins and Food-Dependent Exercise-Induced Anaphylaxis}

Gómez Torrijos E¹, Gratacós Gómez AR², González Jimenez OM¹, Joyanes Romo JB ${ }^{1}$, Palacios Cañas A ${ }^{1}$, García Rodríguez R ${ }^{1}$ ${ }^{1}$ Allergology Service, Hospital General Universitario de Ciudad Real, Ciudad Real, Spain

${ }^{2}$ Facultad de Medicina de Ciudad Real, Universidad de Castilla La Mancha, Ciudad Real, Spain

J Investig Allergol Clin Immunol 2021; Vol. 31(4): 349-350 doi: $10.18176 /$ jiaci.0650

Key words: Anaphylaxis. Exercise-induced anaphylaxis. Food dependent exercise-induced anaphylaxis. Profilins. Panallergens.

Palabras clave: Anafilaxia. Anafilaxia por ejercicio. Anafilaxia por ejercicio dependiente de alimentos. Profilinas. Panalérgenos.

The term anaphylaxis defines an acute, life-threatening, generalized reaction with various clinical presentations that affect the skin and respiratory, gastrointestinal, and cardiovascular systems [1-3]. The occurrence of anaphylaxis after physical activity is known as exercise-induced anaphylaxis (EIA). In about a third of cases, cofactors such as food intake, temperature, and drugs (especially nonsteroidal anti-inflammatory drugs) can be identified [4]. When the associated cofactor is food ingestion, the diagnosis is referred to as food-dependent EIA (FDEIA) [1].

Lipid transfer proteins (LTPs) and profilins are panallergens found in many plant foods. LTPs are a common cause of foodinduced anaphylaxis (FIA) in the Mediterranean area and have also been proposed as a main cause of FDEIA [5]. Profilin, on the other hand, is hardly ever involved in the triggering of FIA, and even more rarely in FDEIA. We present 2 cases of this rare condition.

Patient 1 was a 12-year-old boy with a personal history of rhinoconjunctivitis and asthma due to allergy to grass pollens. He experienced multiple episodes of FDEIA (urticaria, dyspnea, rhinoconjunctivitis, and abdominal pain) during intense exercise, about 30-90 minutes after eating fruit and/or vegetables (peach, pumpkin, carrot, and tomato) (Table). The patient tolerates all fruits and vegetables if he does not take physical exercise and tolerates physical exercise if he does not eat fruits and vegetables during the previous 4 hours.

The allergology study involved skin prick tests (SPTs) with commercial extracts (peach, pumpkin, tomato, wheat, carrot) and prick-prick tests with the fruits and vegetables involved (peach, pumpkin, tomato, carrot, wheat, and pumpkin). All results were positive (mean wheal diameter, $>3.3 \mathrm{~mm}$ ).

The results of SPT with commercial extracts of pollens (grass and olive) and purified palm tree profilin were positive. The results of LTP and other pollens and aeroallergens were negative (total $\operatorname{IgE}, 360 \mathrm{kU} / \mathrm{L})$. Specific $\operatorname{IgE}\left(\mathrm{kU}_{\mathrm{A}} / \mathrm{L}\right)$ was 75 for $\mathrm{rPhl} \mathrm{p} 1+\mathrm{rPhl}$ p $5 \mathrm{~b}$ (Phleum) and 0.6 for rOle el (olive). ImmunoCAP (ISAC, results expressed as ISAC standardized
Table. Demographic, Clinical, and Allergological Characteristics

\begin{tabular}{|c|c|c|}
\hline & Patient 1 & Patient 2 \\
\hline Age & 12 & 28 \\
\hline Sex & Male & Male \\
\hline $\begin{array}{l}\text { Country } \\
\text { of residence }\end{array}$ & Spain (Center) & Spain (Center) \\
\hline Comorbidities & $\begin{array}{l}\text { Rhinoconjunctivitis } \\
\text { Asthma }\end{array}$ & $\begin{array}{l}\text { Rhinoconjunctivitis } \\
\text { Asthma }\end{array}$ \\
\hline Symptoms & $\begin{array}{l}\text { Cutaneous } \\
\text { Respiratory } \\
\text { Gastrointestinal }\end{array}$ & $\begin{array}{l}\text { Oral allergy syndrome } \\
\text { Cutaneous } \\
\text { Respiratory } \\
\text { Gastrointestinal } \\
\text { Hypotension }\end{array}$ \\
\hline $\begin{array}{l}\text { Episodes of } \\
\text { food-dependent } \\
\text { exercise-induced } \\
\text { anaphylaxis and } \\
\text { food involved }\end{array}$ & $\begin{array}{l}\text { Peach, pumpkin, } \\
\text { carrot, wheat, } \\
\text { and tomato }\end{array}$ & Single \\
\hline $\begin{array}{l}\text { Allergy study } \\
\text { Skin tests } \\
\text { (positive) }\end{array}$ & $\begin{array}{l}\text { Grass pollen } \\
\text { Peach, pumpkin, } \\
\text { carrot, wheat, } \\
\text { and tomato }\end{array}$ & $\begin{array}{l}\text { Grass and olive } \\
\text { pollens } \\
\text { Peach }\end{array}$ \\
\hline $\begin{array}{l}\text { Serological } \\
\text { allergy study } \\
\text { (profilins, kU/L) }\end{array}$ & $\begin{array}{l}\text { r Bet v } 2: 2.6 \\
\text { rHev b } 8: 5.1 \\
\text { rMer a } 1: 3.8\end{array}$ & $\begin{array}{l}\text { r Bet v 2: } 20 \\
\text { rHev b 8: } 39 \\
\text { rMer a 1: } 27\end{array}$ \\
\hline
\end{tabular}

units for IgE [ISU-E]) revealed the following values for profilins: Bet v 2, 2.6; rHev b 8, 5.1; and rMer a 1, 3.8. The remaining ISAC determinations were negative. Tryptase was $3.4 \mu \mathrm{g} / \mathrm{L}$

There has been no recurrence of the symptoms of anaphylaxis for the last 5 years, and the patient has avoided intake of fruits and vegetables during the 4 hours before exercise.

Patient 2 was a 28 -year-old man with a personal history of rhinoconjunctivitis and bronchial asthma due to allergy to grass and olive pollens. He experienced a single episode of FDEIA (urticaria, dyspnea, dizziness, hypotension, and tachycardia) during intense exercise about 60 minutes after eating fruit (peach). While eating, he suddenly experienced oropharyngeal itching, runny nose, and sneezing for about 5 minutes (Table). The patient tolerates physical exercise if he does not eat peach or other vegetables during the 4 hours before exercise and tolerates peach, other fruits, and vegetables if he does not exercise.

The allergology study was based on SPTs with commercial extracts (peach, tomato, wheat, carrot) and prick-prick testing with peach and yielded positive results (mean wheal diameter, $>3.3 \mathrm{~mm}$ ). SPTs with pollen extracts (grass and olive pollen and purified palm tree profilin) were all positive. Testing for LTP, other pollens, and aeroallergens was negative.

Total IgE was $1180 \mathrm{kU} / \mathrm{L}$. Specific $\operatorname{IgE}\left(\mathrm{kU}_{\mathrm{A}} / \mathrm{L}\right)$ was 75 for $\mathrm{rPhl} \mathrm{p} 1+\mathrm{rPhl} \mathrm{p} 5 \mathrm{~b}$ (Phleum) and 0.6 for rOle e1 (olive). ImmunoCAP (ISAC, results expressed as ISU-E) for profilins was as follows: Bet v 2, 20; rHev b 8, 39; and rMer a 1, 27. The remaining ISAC results were negative. Tryptase was $2.6 \mu \mathrm{g} / \mathrm{L}$. 
There has been no recurrence of the symptoms of anaphylaxis for the last 5 years, and the patient has avoided intake of vegetables during the 4 hours before exercise.

The first report of EIA dates to 1979 [1,4], when a patient experienced anaphylaxis after eating shellfish and taking exercise. EIA is relatively rare [6,7], with a prevalence of $0.048 \%$ in a large epidemiological study. In Europe, about 30\% of cases of EIA are associated with cofactors $[1,4]$.

The incidence of FDEIA is increasing [6], although the mechanisms involved in development of FDEIA remain unclear. It has been suggested that exercise lowers the threshold of food allergy [8].

While the patients we report had EIA, they subsequently tolerated exercise. Therefore, we suspect that exercise could be an associated cofactor $[1,4]$.

A detailed history allowed us to rule out the involvement of drug and alcohol intake, although both patients had a history of fruit and/or vegetable intake within at least 4 hours before the onset of symptoms. Bearing this in mind, the cofactor in both cases could be a vegetable, since the most important cofactor is food ingestion [1]. Therefore, and given that both patients had a history of pollinosis, we carried out the allergology study with plant foods [6] to detect whether the patients were sensitized to the vegetables they ate.

Gliadin and LTPs are the main allergens involved in FDEIA [9]. As the patients live in the Mediterranean area, we thought of LTP as a possible cofactor [5], although the allergology study showed that neither patient was sensitized to LTP. Findings for profilin were positive. This vegetable protein is generally related to mild reactions, such as oral allergy syndrome, even though we found a case of FDEIA caused by lychee with sensitization to profilins published 25 years ago. In recent years, serious allergic reactions caused by profilins have been reported, especially in areas of high exposure to grass pollen, because allergic asthmatic patients are frequently sensitized to profilin $[1,10]$.

Based on the finding of food intake, symptoms, and the results of the allergology study, both patients were diagnosed with FDEIA by profilin [10].

FDEIA is a rare but serious condition that can have a significant impact on patients' lives [7]. Moreover, early diagnosis and identification of the associated cofactor is essential, because if a vegetable panallergen is involved (as in the cases we report), it is very important to initiate early treatment with epinephrine (autoinjector) and prevent further episodes by providing adequate information on cross-reactivity between vegetables [1]. Exercise should be avoided for at least 4 hours after eating causal foods.

Overall, in severe reactions such as FDEIA, profilin should be considered a trigger allergen, especially if the patient lives in an area of high exposure to grass pollen.

\section{Funding}

The authors declare that no funding was received for the present study.

\section{Conflicts of Interest}

The authors declare that they have no conflicts of interest.

\section{References}

1. Pravettoni V, Incorvaia C. Diagnosis of exercise-induced anaphylaxis: current insights. J Asthma Allergy. 2016;9:191-8.

2. Simons FE, Ebisawa M, Sanchez-Borges M, Thong BI, Worm M, Tanna LK, et al. Update of the evidence base: World Allergy Organization anaphylaxis guidelines. World Allergy Organ J. 2015;8:32

3. Gómez-Soler R, Caballero ML. Incidence of Anaphylaxis Recorded During 1 Year by the Municipal Emergency Service of Madrid (SAMUR-PC). J Investig Allergol Clin Immunol. 2018;28(6):438-40.

4. Medrala W, Cieślik K, Barg W, Skotny A, Siwak E, WolanczykMedrala A. Naproxen Increases the Severity of FoodDependent Exercise-Induced Anaphylaxis: A Case Report. J Investig Allergol Clin Immunol. 2014;24(6):439-62.

5. Mota I, Gaspar A, Benito-Garcia F, Correia M, Arêde C, Piedade $\mathrm{S}$, et al. Anaphylaxis Caused by Lipid Transfer Proteins: An Unpredictable Clinical Syndrome. Allergol Immunopathol (Madr). 2018;46(6):565-70.

6. Benito-Garcia F, Ansotegui IJ, Morais-Almeida M. Diagnosis and prevention of food-dependent exercise-induced anaphylaxis. Expert Rev Clin Immunol. 2019;15(8):849-56.

7. Foong RX, Giovannini M, du Toit G. Food-dependent exerciseinduced anaphylaxis. Curr Opin Allergy Clin Immunol. 2019;19(3):224-8

8. Asaumi T, Ebisawa M. How to manage food dependent exercise induced anaphylaxis (FDEIA). Curr Opin Allergy Clin Immunol. 2018;18(3):243-7.

9. Bartra J, Araujo G, Muñoz-Cano R. Interaction between foods and nonsteroidal anti-inflammatory drugs and exercise in the induction of anaphylaxis. Curr Opin Allergy Clin Immunol. 2018;18(4):310-6.

10. Rodríguez Del Río P, Díaz-Perales A, Sánchez-García $S$, Escudero C, Ibáñez MD, Méndez-Brea $P$, et al. Profilin, a Change in the Paradigm. J Investig Allergol Clin Immunol. 2018;28(1):1-12.

Manuscript received June 15, 2020; accepted for publication October 9, 2020.

Elisa Gomez Torrijos Hospital General Universitario de Ciudad Real C/ Obispo Rafael Torija s/n 13005 Ciudad Real, Spain E-mail:egomezt.cr@gmail.com 